\title{
RECIPES FOR LOVE IN THE ANCIENT WORLD ${ }^{1}$
}

\section{Vivienne Lo and Eleanor Re'em}

Throughout history, a huge amount of attention has been devoted to aphrodisia. Yet, in historical research, they tend to feature only in passing comments in studies of love, sex and the emotions, or of food and medicine. The relative absence of monographs on the subject is, therefore, a significant lacuna. ${ }^{2}$ This chapter will argue that it is particularly a lacuna in the history of science, medicine and empiricism. ${ }^{3}$ Aphrodisia, as a subject involving products and practices that have induced sexual pleasure, allow us to contribute to the 'sensory turn' in history. Calling to mind the aesthetics of an ancient world where the boundaries between what we now think of the domains of individual senses were less distinct, aphrodisia give us privileged access to the gathering of medical knowledge before the observation of the eye took its post Enlightenment pride of place in the conduct of science. ${ }^{4}$ The subject permits an 'inquiry into the conditions under which knowledge, or what passed for it, was produced, and the conditions under which those who claimed to do the producing worked'. ${ }^{5}$ It also leads inexorably to an investigation of the history of the "scientific self" and self-experimentation. In what terms did learned people perceive the world in ancient times? These are key issues in comparative histories of knowledge production.

\section{ACADEMIC AMNESIA}

A related case of modern academic amnesia is the erasure of the erect penis from the face of the history of civilisation. In the words of Simon Goldhill, "the way we differ from the ancient worlds is also profoundly telling about the taboos and anxieties which shadow the modern sense of the self'. ${ }^{6}$ He illustrates the enormous erect phalli that populated the worlds of ancient Greece, in religious statu-

\footnotetext{
${ }^{1}$ We are deeply indebted to friends who have helped us with this research: Donald Harper, Vivian Nutton, John Wilkins, Penelope Barrett, Andrew Wear and Laurence Totelin. We also thank the editors of the volume for invaluable comments.

2 Important exceptions include Faraone 1999, Faraone and Obbink 1991; Harper 1998; Umekawa 2005.

${ }^{3}$ In this chapter we use the term 'empiricism' in both its usual senses. The first refers to the practice of medicine where practitioners, and communities, choose treatments in a logical fashion according to what, in their experience, is deemed to work; and they do not need to know why according to any guiding theoretical framework. The philosophical usage of the term opposes empiricism (anything based on experience) to a priori knowledge arrived at from first principles. Both types of knowledge make claims to universal validity and, notably, a number of philosophers use both. Descartes would provide an example of the latter, though he questioned whether the model of the world derived from first principles was actually so in the experienced world.

4 Jütte 2005: 25 -31.

5 Lloyd 1996: 16

${ }^{6}$ Goldhill 2004: 29; See also Keuls 1993: 75-79.
} 
ary and civic ritual, celebrating Dionysus in the world of entertainment, and as smaller day-to-day objects, sometimes winged, candle-holders and door pulls. ${ }^{7}$

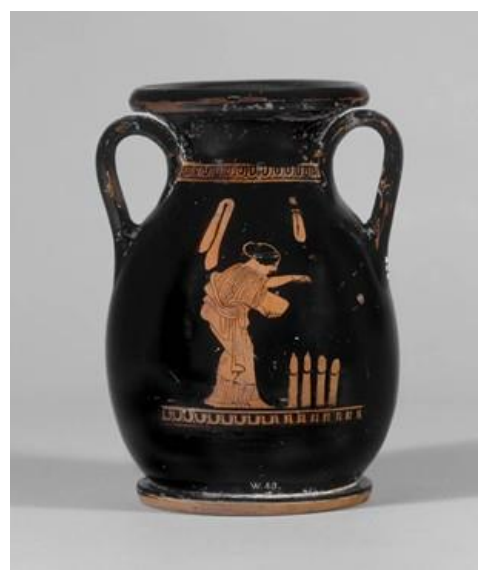

Figure 1: Red-figure pelike, attributed to the Hasselmann Painter, BM1865,1118.49.

The erotic power of phalli was not limited to mundane sexual engagement. A little known and unique red-figure pelike depicts a woman watering erect phalli as if they were plants. There is later European testimony to this harvesting of disembodied penises by women, a subject crying out for gender analysis: perhaps a joke about male anxiety over the cuckold (it's likely to have been produced by a man), loss of virility, or the sexual power of the woman in the kitchen (she might cook them), a connection with mystic ceremonies of Athenian women, such as the Thesmophoria? Some phalli had an apotropaic function to protect the state, community and household, marking the boundaries of the Athenian world. Where erect phalli were part of Greek 'furniture of ancient religion and social life', in China they seem to have been a common feature of funerary furniture. Huge bronze

${ }^{7}$ Goldhill 2004: 30-33. 
examples, one double shafted, have been found decorating the tombs of wealthy

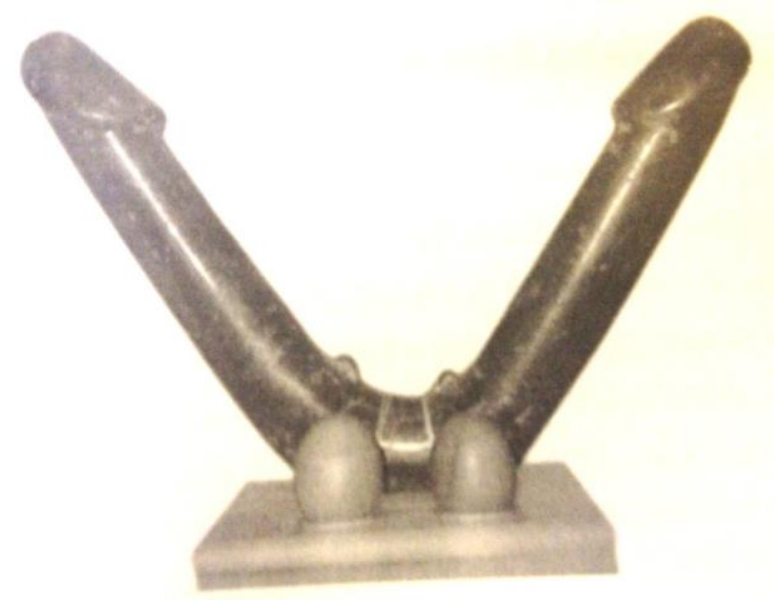

nobles. $^{8}$

Figure 2: Double phalli from Tomb M1 Mancheng, Hebei.

In this context they evoke the potency of images of sexual prowess in sustaining the power of the body, even beyond death. During the $20^{\text {th }}$ century these phalli were one of the most consistently ignored features of ancient Chinese archaeology. ${ }^{9}$ The quantity of aphrodisiac texts from the ancient Chinese world has also gone relatively unacknowledged and the survival of their knowledge in modern Chinese pharmacology texts goes virtually unacknowledged.

8 Goldhill 2004: 34.

9 Erickson 2010: 80; Li Ling 2006: plate 8.1-3. 


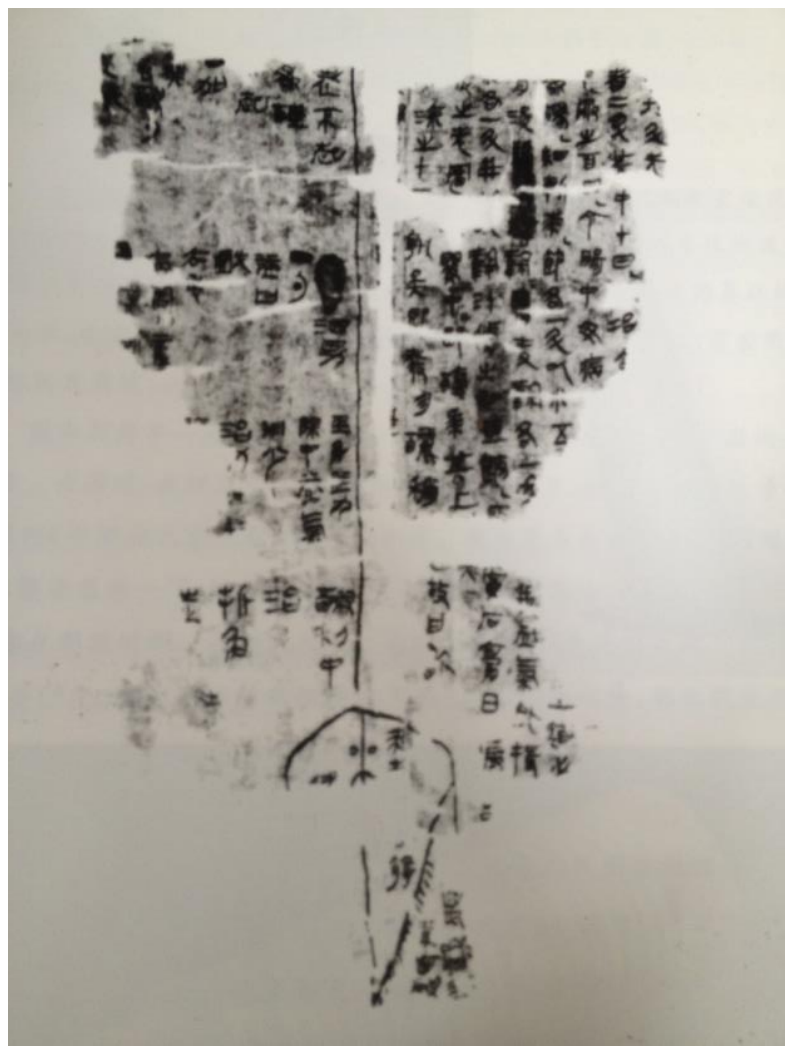

Figure 3: A chart of the Vulva. Mawangdui tomb 3 (closed 168 BCE)

Twentieth-century censorship of the ancient world's preoccupation with aphrodisiac drugs is also apparent in Sir Arthur Hort's 1961 translation of Theophrastus of Eresos' (c. 370-288/85 BCE) fourth century BCE Historia Plantarum (Enquiry into Plants, hereafter HP), the work that Scarborough claims 'formed the basis for all succeeding studies of plant lore classifications until Linnaeus'. ${ }^{10}$ Sir Arthur omitted the section 9.18.3ff about the Orchid (oxpxıs [testicle]) 'on account of the description of the physical effects', testifying to the existential crisis of many historians of the time. The omission elicited the objection: 'Such prudishness in a scientific book is truly shocking.'11 Fifty years later we can do better. Surely, the nature of these 'physical effects' is of prime importance to a history of selfexperimentation and empiricism. Like the erect phallus, aphrodisia have also been pervasive not only in the social and religious performance of wealth and power.

\section{DEFINITIONS AND SOURCES}

\footnotetext{
10 Scarborough 1978; 2010.

${ }^{11}$ As quoted in Gemmill 1973: 127-9; Sarton 1959, vol. 1: 555. For a translation of the missing section see Preus 1988: 88-91.
} 
The major challenge of comparative history is surely to find commensurate contexts across cultures and time that facilitate matching case with case. Aphrodisia, as we understand the Greek term, represent all those techniques to entrap and enhance sensual love, sex and beauty traditionally associated with Aphrodite: cosmetics, binding spells, drugs to enhance performance and attraction. This range of topics is also conveniently germane to related evidence from ancient Chinese literature.

Greek and Roman sources for aphrodisia in this broad sense include the writings of the philosophers and naturalists such as Theophrastus, the medical treatises of the Hippocratic writers (fifth to fourth centuries BCE), and Pliny (23-79 CE), as well as Greek and Roman poets and playwrights such as Ovid (43 BCE - 17/18 $\mathrm{CE}$ ), Archestratus (fourth century BCE) and the Attic comedians as cited by Athenaeus (c. second-third centuries BCE). Information on ancient Greek products that create sexual pleasure and promote competence is quite common in ancient medical literature. Materia medica will mention when a product is aphrodisiac among other indications of its efficacy in treating illnesses and promoting health. Spellbinding texts permit access to the circumstances of everyday love. For love magic, the Greek magical papyri, the works of Julius Africanus and the Greek magical papyri (to fifth century CE), including the demotic Egyptian handbooks provide direct testimony to practices that we know survived from the ancient into the medieval world. ${ }^{12}$

For China, our major focus for aphrodisia is also recipe and spellbinding literature from the Western Han tomb at Changsha Mawangdui 馬王堆 (c.168 BCE), of the old Han kingdom of Chu 楚. ${ }^{13}$ Later testimony to the survival of the relevant recipe literature is taken from among the Dunhuang manuscripts (sealed in Cave 17, c. 1035. As in early Greek medical writing, the authors of these recipe texts were anonymous individuals and in the Greek case their work was compiled into large textual corpora. Their findings speak of the collective memory of countless individuals who contributed to establishing and disseminating ancient scientific knowledge across a millennium.

To understand the broader theme of the emotions we also have to scan earlier philosophic literature of the Warring States (475-221 BCE), here texts attributed to Mencius 孟子(fourth century BCE), and Xunzi 旬子 (c. 313-238 BCE). Our analysis is therefore of the Greco-Roman worlds and China before the first century of the first millennium, with reference to later literature that testifies to the continuity of some traditions. In both Greco-Roman and Chinese worlds this was the period in which one can see major systematisation of medical theory. We could equally be talking of Indian aphrodisia, except that the Sanskrit texts that we

\footnotetext{
12 Viellefond 1970; Faraone and Obbink 1991.

13 The Mawangdui burial mound was excavated in the early 1970s. It contains three tombs. Tombs no. 1 and no. 2 belonged to the Marquis of Dai (軑侯), Li Cang 利蒼 (died 186 BCE), and his wife (tomb no. 1). Tomb no. 3, from which the manuscripts were excavated, was occupied by their son, who died in 168 B.C. at the age of about 30 . For the excavation report see Hunansheng bowuguan and Zhongguo kexueyuan kaogu yanjiusuo 1973: 39-48.
} 
might consider, like Kāma Sūtra, are composite texts generally dated to around the third century CE and extant from much later. Moreover, in the case of recipes that tie together longevity and sexual prowess - in the process of vajikarana -

those texts (e.g. Caraka samhitā and Suśruta samhitā) are notoriously difficult to date and mainly promote milk products for their impact on ojas (vital essence) drawing on the association of milk with semen (sukra). The Greco-Roman contexts provide a much richer and more coherent comparison.

\section{LOVE, SEX AND APPETITES}

'Love' is the most difficult of the categories to compare. Different types of passion and affection moved the ancient Greeks: eros, storge, philia, and agape. Storge, understood as the love of a parent for a child and familial bonds of emotion, seems hardly relevant to aphrodisia; agape, as the kind of human heartedness that overrides selfishness, seems devoid of the kinds of feelings or lust attendant on sensual love. Physico-emotional passions crystallise in the term eros, with potentially unwanted lust, and torture, or in philia. The word philos was used to describe the family and its close, intimate associates or to describe a philosophical group. ${ }^{14}$ Philia was a complex emotion: inspired by people with whom one has certain reciprocal commitments, where we also find the encompassing familial feelings of delight and warmth. It was an emotion that might elicit a kiss and embrace or equally hetero or homosexual intercourse with affection. ${ }^{15}$

Modern scholars searching for love in ancient China have also failed to find tidy categories. Attention has centred on the words ai 愛 and qing 情 (note the modern word for mood or state of emotions, qingxu 情緒), and we add here also qin 親, which broadly means 'to treat someone as if they were kin'. In the Warring States, qing meant something like 'one's natural endowment' and from Han times, it was assimilated to an 'array of notions' concerned with passion and emotion. ${ }^{16} A i$, the modern word for 'love' between lovers and family members, as well as for expressing preferences such as an appetite for particular foods, is no less ambiguous. Closely associated in philosophy with 'universal love' or 'love for each and every one' as promoted in the school of Mozi (c. 5th- $3^{\text {rd }}$ centuries BCE), ai was a transcendent feeling of benevolence as well as sexual love.

\section{THE SENSORY TURN}

\footnotetext{
14 Humphreys 1983: 67. Humphreys notes that 'the term philios overrides the distinctions we make between love, family and friendship'. The conventional translation of philos as 'friend' might suit the philosophical context but not the familial.

${ }_{15}$ Faraone 1999: 29-30; For discussions of homosexual, familial and marital love see Humphreys 1983: 17-18, 42-43, 54-57, 66-78.

16 Andreini 2006; See also Allan 1997: 85.
} 
Since the early 1990s there has been increasing research into how the sensory base of emotion operates in different scientific cultures. Rather than cultivating emotional detachment, as was the prescription for objective and unfettered observation among mid nineteenth century scientists, early Chinese scholars trained themselves as knowledge gatherers through training their bodily qi, a term which came to codify and communicate inner body sensations. This cultivation of learned recorders of the world, their epistemic virtue, meant that the self, the perceiver, embodied what was perceived. ${ }^{17}$ Constellations of meaning gathered around the notion of $q i$ in the literate communities of ancient China and contributed to a remarkable ability to articulate changes in the inner landscape of the body in their relation to the wider environment. This community attention to the inner world is what might be called an early Chinese 'sixth sense', the cultivation of which enabled the management of digestion, body temperature, emotion, passion and pain, the impact of drugs and breathing. These intimate experiences of the inner body were placed on a synesthetic continuum with experiences of the external world: seasonal affect, the influence of the heavenly bodies, ancestral and other spirits. Initially acting as a social marker that distinguished the selfcultivation of the nobility, a repertoire of qi techniques also began to shape the rituals and language of medical practice at the beginning of empire. ${ }^{18}$

Experiments with pleasure found in the earliest extant texts that theorise sexual cultivation were the ground upon which a new medical language of Yin, Yang and qi was first constructed - a kind of knowing that informed classical treatises on acupuncture and drugs and that, being mediated through the body, never aspired to levels of pure abstraction. ${ }^{19}$ These new techno-physiologies of the body were premised on the authority of pre-existing writings that were more philosophic in tone and sought to restrain the consumption and display of material wealth. Writings attributed to Xunzi (early third century BCE) recognised delayed gratification and the 'sustaining' or 'connoisseur' pleasures as the mark of the socially stabilising figure of the 'gentleman'. ${ }^{20}$ In Xunzi, we find reference to a body-centred practice in which calming the heart and clearing it of anxiety was a key to a deeper and more prolonged appreciation of pleasure - a pleasure that eschewed the loud, brash and gaudy in favour of the refined appreciation of senses honed to simplicity. ${ }^{21}$

The sage ruler was a 'perspicacious' individual who comprehended the deep structures of the universe through a heightened acuity of the senses. Sensory perception 'was valued as a genuine part of moral reasoning in ancient China'. ${ }^{22}$ Thus gluttony and the uncivilised pursuit of sexual satiation were contemptible, but the pursuit of culinary finesse and the mastery of sexual techné belonged to the highest domain of gentlemanly pursuits. The rationale behind male sexual continence, an anxiety shared across the ancient worlds, was that the more

\footnotetext{
17 Daston and Gallison 2007: 39-41.

18 Lo 2001: 19-51.

19 Lo in Bray et al 2007: 383-424.

20 Nylan 2003: passim.

${ }^{21}$ Nylan 2003: 73-124.

22 Sterckx 2003: 72.
} 
pleasure a woman had, the more benefit there was for the man. Her pleasure was a correlate of the extension of qi through her body. ${ }^{23}$

Practical substance in the form of instruction to the man was given to this techné of the senses in the literature and culture of self-cultivation. ${ }^{24} \mathrm{He}$ must learn to recognise, respond to and codify all the stages of female arousal: her aromas, sounds, breathing and movements, the feeling of being inside her. The qi in a sensory experience cognate today with orgasm) emanated from the zhongji 中極 Middle Extremity. By the first century CE this term referred to an acupuncture point, but in the second century BCE it had simply been a lyrical anatomical term for the area in the general vicinity of the uterus. At the moment of the woman's orgasm the male partner absorbed the Yin essences of the woman, through the physiological interaction of the essences that occurred with the extension of $q i$ in the female body, and the concomitant expression of the emotion of love: If only he can be slow and prolonged, the woman then is greatly pleased. She qin 'treats him with the closeness she feels for' her brothers, and ai 'loves' him like her father and mother. ${ }^{25}$

At the height of her rapture the woman is apparently overcome with feelings for her sexual partner akin to those she feels for her siblings and parents. As if this isn't uncomfortable enough for a modern reader, the man, reserving his orgasm, is simultaneously deriving an increment to his health and strength from the Yin essences emitted by the woman at the point of orgasm -- which resulted in a state of shenming 申明, a brilliance of the spirits for him (and possibly for her).

Recording the essential characteristics of female sexual response were a key to this process. They inhabit a larger discourse with a specialist terminology which interlinked restraining pleasure with the generation of the cosmos, so that 'whoever is capable of this way is designated 'heaven's gentleman'. ${ }^{26}$ We can already detect that the quality of writing in this technical literature does not reveal the kind of separation between philosophical and technical writing evident in Aristotle's (384-322) hierarchies of knowledge. To Aristotle the techné of the physician was inferior to the larger rhetorical skills concerned with philosophy, and it was limited by its utilitarian ambitions. ${ }^{27}$ That is not to say that Aristotle eschewed knowledge acquired via the senses. Far from it. The four primary qualities that he espoused were known mainly through touch: hot, cold, dry and wet. But while it was perfectly possible for a philosophically sophisticated doctor to investigate causes and so be 'scientific' according to Artistotle's criteria, the study of medicine alone was insufficient. Only the freedom of leisure and plenitude would create the conditions for pursuing natural philosophy, and the correct synthesis of rational thought and empirical knowledge to understand the body. Rather, the learned

\footnotetext{
23 Pfister 2012: 34-64. AWD 4156.

24 Lo 2001: in Bray et al 2007.

25 Harper 1998: 438. MWD 4 (He Yinyang) nos. 66-67

${ }^{26}$ lbid.

27 Wear 2013: 63 n.7, n.8.
} 
physician must enhance the status of his knowledge and practice through an inquiry into first principles, fundamental propositions about the nature of the world, a view echoed later by Galen in his treatise The Best Physician is also a Philosopher. $^{28}$

Famous polarities of opinion, however, provide evidence of the diversity of attitudes towards the knowledge and practice of medicine and healing in the GrecoRoman world, and the figure of the practitioner: famously the Hellenistic medical sect, the Empirics valued experience alone, finding an early empiric in Hippocrates. ${ }^{29}$ An Hippocratic author of the fifth century treatise Ancient Medicine thought that 'medicine should have its own knowledge independent of philosophy'. ${ }^{30}$ For the Empirics, whose work echoed this Hippocratic sensibility, much of the search for first principles and the causes of illness was pointless activity. Valuable knowledge came, for example, from the serendipity of drug discovery, together with the recording and re-recording of drug effects, and trial and error. ${ }^{31}$ Already in the sustained attention to this process we can see a trained observer mediating simple collective empiricism with specific ways of framing the medical object, methods which we will see brought to the nature of sexual stimulation in the next section.

\section{SEXUAL CONTINENCE}

Early Chinese and Greeks alike left records about the sexual body. For the authors of the Mawangdui aphrodisiac literature knowledge about the body required a particular kind of preparation, and one in which expertise in the sexual arts provided enhanced insights. The anonymity of the authorial process suggests a collective knowledge, with acquisition of a shared language, resulting from personal experimentation. By suppressing ejaculation, a man strengthened his qi and jing 精 and gained an increment of youth and vitality. This appears to be a rather dispassionate and medical approach to sex, which pursued enhanced health, altered states of spiritual sensibility, power and longevity for the male partner - later texts even claimed that intercourse with multiple female partners would lead to immortality. The following excerpt is the outcome of a technique that includes both breath and sexual cultivation:

...in drinking wine and eat the five flavours; put the qi in order with intent and the eye will be bright, the ear keen, the skin will gleam, the one hundred mai will be full and the Yin will rise again. From this you will be able to stand for a long time, go a long way, and live for (ever). ${ }^{32}$

\footnotetext{
28 Wear 2013: 63 n.4. (K 1.53-63).

29 Lloyd 1987: 158-162.

${ }^{30}$ Quoted in Wear 2013: 63, n. 9.

31 Nutton 2004: 149-151.

${ }^{32}$ MWD 4 (Shiwen) nos. 40-41. Ma 1992: 914. See also Harper's note on the re-ordering of the bamboo strips by Qiu Xigui. Harper 1998: 396-7 n. 8.
} 
The focus here was not on procreation but on the more esoteric benefits of abstinence from indulgence, strengthening Yin, the word 'Yin' being construed as the penis itself, but also the Yin qualities of the body - its coolness, its moistness, the health of the internal organs and thus the ability to endure both in terms of sexual continence and long life. For men the concern for increasing potency was founded on a fear that, through the loss of the most precious essence and the source of life, ejaculation would deplete their power.

The man who wished to distinguish himself as a learned gentleman had to become a micro-technician of the senses. By the second century BCE practices that trained the appetites involving food, sex and breath cultivation techniques formed the key context within which new physiological ideas emerged. Healing and sustaining a powerful body was thus codified with a new science of the senses. As these anonymous writers began to document an aesthetic experience of how it felt inside to be well and strong, of experiences of desire and pleasure, of digestive satisfaction, of sexual excitement, they created a language of Yin, Yang and qi with sufficient semantic traction that it was able to convey the changing states of the inner sensory world. ${ }^{33}$

Good health was not consistent with male ejaculation, neither in ancient China nor Greece. Aristotle described the mystical qualities of semen that were related to a divine aether. ${ }^{34}$ The Hippocratic treatise Generation notes that a man's seed is drawn from all parts of the body, and particularly its moisture, making it the most powerful part of his make up so that 'when we have intercourse we become weak' with the loss of 'the most potent and richest' essence of all the bodily fluids. ${ }^{35}$ Sexual stimulation produced a warming of the body followed by agitation. The combined effect was thought to produce fluidity and foaming (aphrein), which travelled to the brain and down the spinal marrow to the loins. Sperm was then foaming blood that arose from disturbance (taraxis) produced by innate heat. ${ }^{36}$ Since it exited the body in a sudden spasm the man's pleasure was brief and his health compromised.

The subjugation of women's health and pleasure to her power of generation is confirmed throughout Greco-Roman medical writing. Generation sets out a rather mundane physiology of sexual processes that stresses reproductive health and the health of progeny. On the Nature of Women also recommended having children for general health. Regular sex moistened and plumped up the womb and was a cure for many diseases. Illness came to unmarried women. ${ }^{37}$

Female desire and pleasure were a pre-condition for conception: 'When women have finished having their periods, they conceive (hold in the belly) especially

\footnotetext{
${ }^{33}$ Lo 2000; 2001: 19-51. The faculty of sight was least competent at perceiving any form of internal qi. External qi was visible as clouds, steam, or the dust and threat of, say, a distant army. Most books on the senses ignore the undifferentiated sea of sensation within the body. See Geurts 2005 for a study of the 'panopoly of inner states' described as seselelame in West Africa. For the perception of touch see Kuriyama 2002 and Hsu 2010.

34 Lonie 1981: 100.

${ }^{35}$ Alter 2013: 138. For Hippocrates Generation 1 see Potter 2012: 1-24.

${ }^{36}$ Lonie 1981: 101.

37 Potter 2012: 194-197.
} 
when they feel desire', a point which rather contrasts accepted notions of the separation of lust and family affection in the concept of agape. A woman disengaged or forced into sex might not conceive for the seed would flow out of her uterus. 'Love (agape: desire and affection conjoined), on the other hand, made the seed fit together and .... intercourse with passion (eros) produces children much faster. ${ }^{38}$ Compared to the sudden male spasm, women's pleasure was protracted. Ideally, to maximise eugenic potential both partners would achieve simultaneous orgasm. A healthy constitution and strong sperm/sperma in both parents together with a co-ordinated climax would produce a strong child. In a resolutely androcentric approach to female sexuality, however, we learn that the woman stopped enjoying sex once she had captured the sperm. Pleasure was but a necessary side-show, not an end in itself.

In summary, ancient physiologies of sex and reproduction were clearly gendered in the ancient worlds, and delivered alongside prescriptions for avoiding loss of sperm/sperma or the finest qi in the Chinese context. In the case of the Hippocratic writings the medical view was trained on the circumstances that would enhance fruitful reproduction rather than the pursuit of pleasure. In the Chinese sources reproduction was only tangential to social, aesthetic and health considerations. In both cases, Greco-Roman and Chinese, the primary sources allow us to consider the epistemic virtues implicated in the cumulative, long-term practices of noting and recording sexual activity.

\section{LOVE CHARMS AND BINDING SPELLS}

The combative nature of sexual engagement, its violent spasms (tarachē), the weakening of the body, can be seen in other less noble and gentlemanly domains of Greco-Roman life, and in a very different kind of text that belongs to the realm of cursing. Greek magical papyri describe techniques to entrap the objects (sometimes multiple women), of a man or woman's desire. Sometimes the spell aimed to work literally through tormenting a woman's body supernaturally with erotic spells so she would feel, 'the (?) longing as a she-cat (5) feels for a male cat, ... ' 'a yearning, a love, a madness great....she seeking for him (going) to every place', the fury (10) 'of Yaho, Sabaho, Horyo...: for I cast fury on you' : until such time that she succumbed, and thereby released herself'. ${ }^{39}$

The Greek magical papyri tend to date from the latter part of our time period until the fifth century CE, but their form, siting and purpose connect them to the defixiones, the curse tablets, for which there are examples from as early as the late fifth and fourth centuries BCE. ${ }^{40}$ As Faraone points out, the spells aim at controlling the ardent male while arousing the passive female. ${ }^{41}$ References to passionate women's spells are also to be found in the Idylls of the bucolic poet Theocri-

\footnotetext{
38 Aetius (16.26) translated in Parker 2012: 116.

39 Tr. Griffith and Thompson 1921: 185.

40 'Nestor's Cup Inscription' is one such inscription. If a man drunk from it he would be seized by a passion for sex. See Faraone 1996: 19.

41 For Pliny as a later Roman source, see McClure 2002: 236-7. On the gender politics of Greek love charms, see Winkler 1992: 90-91, 95-98.
} 
tus. Here in extracts from Idylls 2, the discomfort of sickness and the torment of erotic seizure seem to elide:

I bind you, Theodotis daughter of Eus, by the tail of the snake and by the mouth of the crocodile and by the horns of the ram and by the venom of the asp and by the whiskers of the cat and by the penis of the god, that you may not be able to have intercourse ever with another man either frontally or anally, nor to fellate nor to take pleasure with another man except me alone Ammonion Hermitaris. ${ }^{42}$

Some of the speakers are clearly female, aiming to draw and compel the man:

[1] Where are the bay-leaves, Thestylis, and the charms?

Fetch all; with fiery wool the caldron crown;

Let glamour win me back my false lord's heart!

Twelve days the wretch hath not come nigh to me,

Nor made enquiry if I die or live,

Nor clamoured (oh unkindness!) at my door.

Sure his swift fancy wanders otherwhere,

The slave of Aphroditè and of Love.

I'll off to Timagetus' wrestling-school

At dawn, that I may see him and denounce

His doings; but I'll charm him now with charms ${ }^{43}$

Or resolve love-madness:

[22] First we ignite the grain. Nay, pile it on:

Where are thy wits flown, timorous Thestylis?

Shall I be flouted, I, by such as thou?

Pile, and still say, 'This pile is of his bones.'

The last in this sequence introduces the linking of animals and aphrodisia:

[52] The coltsfoot grows in Arcady, the weed

That drives the mountain-colts and swift mares wild.

Like them may Delphis rave: so, maniac-wise,

Race from his burnished brethren home to me.

There is also evidence that spells were generic forms into which the cursors would insert their, and their would-be-lovers' names, invoking the interventions of common Goddesses and animal spirits, spells of fire and the symbolic power of

42 Winkler 1992: 94; Jordan 1985.

43 Theocritus Idylls II tr. Calverley 1892. 
herbs. Binding spells in the ancient Greco-Roman and Chinese worlds shared many features: categories of ingredients such as those belonging to the so-called Dreckapotheke, that is the use of human and animal parts such as faeces, nails and hair; incantations, and magical writing. The spells are recorded and inscribed, however, in quite different ritual contexts, in remedy collections, poetry, inscriptions, historical records as well as in the curse tablets.

Allegations of spellbinding and the burying of wooden manikins by palace women to secure the interest of the Han emperors provide well-known stories from the standard histories about early Chinese love magic. ${ }^{44}$ The Mawangdui medicodivinatory literature provides further evidence of the use of binding spells, outside and far from the palace. ${ }^{45}$ This more direct evidence implies that a third person was responsible for the spells, perhaps a member of the family, but more likely someone charged especially with, and charging for, this kind of ritual service. Here is an excerpt from the Mawangdui text given the modern title of 'Za jinfang' 雜禁方. ${ }^{46}$ The art of seduction and binding of lovers seems to be integrated into a category of spells concerned with creating and/or disrupting social harmony: separating, as well as bringing together couples; harmonising mother/daughterin-law relations; stopping dogs barking.

[1] Where there is a dog that likes to bark in the courtyard and gate, daub mud on the well, in a rectangular band five chi long. When the husband...

[2] $\quad .$. and wife dislike one another daub mud on the doorway $X$ in a rectangular band five chi long. When you wish to seduce a noble person, daub mud

[3] ...on the left and right sides of a gate in a rectangular band five chi long. When you have frequent foul dreams, daub mud beneath the bed

[4] ...in a rectangular band seven chi long. When the husband's mother and his wife like to fight, daub mud on the doorway in a rectangular band five chi long. When an infant

[5] ...likes to cry, daub mud on the window in a rectangular band five chi long.

[6] When involved in a suit with another person, write the person's name and set it inside a shoe.

[7] Incinerate and smith the tails of two female doves. Drink it yourself, and seduction will occur.

[8] Take quantou that faces east-west. Incinerate and smith. Give it to the husband and wife to drink, and they will be driven apart.

[9] Take four nails from the left claw of a male dove and four nails from the left hand of a young girl. Scorch in a saucepan, combine and smith. Apply it to the person and the person will be obtained.

${ }^{44}$ Loewe 1974: 42, 81.

45 See Li Jianmin 1996: 8.

46 See Liu Lexian 2005, tr. Lo. 
[11] Put the person's left eyebrow in liquor and drink it. You invariably obtain the person.

This miscellany of spells to bring people together and drive them apart, to resolve household disharmony, and to create it, was buried in a box at Mawangdui tomb 3 together with other literature dedicated to the healing arts and stored separately from works on philosophy, statecraft, and astronomy etc. The selection indicates an early form of meta-categorisation concerned with the techné of the body and its emotions, in this case directed by the funerary director. The categories also mirror, very closely, the fangji 方技(recipes and techniques) bibliographical category of the Han imperial library (recipe literature, theoretical treatises, the arts of the bedchamber and immortality). ${ }^{47}$ This eclectic approach has to be understood as a feature of the systematisation of medicine in Han times, integral to the larger processes of synthesis common to imperial administration.

Spellbinding literature of Chinese origin in a $10^{\text {th }}$ century Japanese medical compilation and the divinatory and medico-technical writings of the Dunhuang manuscripts suggest the geographic and temporal range of this tradition. ${ }^{48}$ Here the first four spells of Rang nüzi furen shu mifa 攘女子婦人述秘法 (Detailing the secret art of stealing women), are actually concerned with binding one's own husband:

[103] Whenever you wish to make [your] husband love [you] get the earth from under a red dog's feet and place it below his navel. He will immediately love the wife.

[104] Whenever you wish to attract your husband's love and respect, get his thumb nail and burn it to ashes, mix with wine and take it. Tested.

Chinese and Greek spellbinding involved strategies to resolve the discomforts and desires of passion. It assumed the intervention of spirits, the power of incantation, the resonances between things that are alike, be that the nails of the lover pursued and the claws of a bird, a manikin resembling the object of desire, or the power of rectangular mud symbols when daubed on the walls.

The question of how to evaluate perceptions of the efficacy of spellbinding deserves a sustained analysis which is certainly beyond the scope of this chapter. While there have been many important contributions to this question, notably from medical anthropologists, it is not enough to attribute the impact of ritual techniques to a psychological 'placebo' or an anthropological 'meaning re-

\footnotetext{
47 Hanshu 6.1776-80.

48 Ishinpō, juan 26. Cf Qiu Xigui 1992; Li Ling 2001; Li Jianmin 1996. See P.2661, P.2666 and P.2610.
} 
sponse', solely effective within particular cultural parameters. ${ }^{49}$ Modern attempts to explain cause and effect within a discourse of social meanings fail to explore how shared and repeating ritual behaviours gather and preserve knowledge, the efficacy of which is understood differently as time goes by. This is easiest to understand when the ritual involves the sustained ingestion of particular substances. The transition from burning of artemisia annua to determine an environment safe from malevolent disease-causing spirits, to its use in drawing and strengthening qi and the treatment of intermittent fever, to its ingestion as modern public health drug of choice in the prevention of malaria is a case in point. The sustained attention to the effect of the plant involves observation and recording within changing, but still linked, ritual, epistemological, and institutional domains.

Love charms and binding incantations were often used together with substances considered potent in the arts of love and seduction. The latter may have included tonics put into food or drink or ointments to induce sexual passion in another person. ${ }^{50}$ In the next section we turn to the aphrodisiac drugs and recipes themselves which reflect a practice of self-medication, the key techné upon which the coming argument about empiricism and the senses rests

\section{THE RECIPES}

... apart from powers for health and disease and death, they say that herbs have other powers not only on bodily things but also on those of the soul. I mean by 'bodily' those concerned with generation and infertility. In fact some (plants) do both from the same part, for example the so-called orchis [testicle]; for as there are two <roots>, a large and small, the large root, if given in milk of a mountain goat, makes one more functional for intercourse; the small one harms and prevents. This plant has a leaf like the squill but smoother and smaller; the stem is very like that of the euphorbia used in unburnt offerings (Theophrastus 9.18.3). ${ }^{51}$

Where historical aphrodisiac recipes were placed, categorised and how they circulated reveals a great deal about their role in the ancient world. Just as culinary and medical recipes, they were not merely a guide to practice, they also represent a record of the collective imagination of that practice. In all there are some 1500 recipes in the Hippocratic Corpus, and most of the aphrodisiac recipes lie in the gynaecological treatises. ${ }^{52}$ Totelin emphasises large areas of overlap in antiquity between cosmetological, gynaecological and sex manuals and all the recipes had procreation as one of their main purposes. This reproductive aim did not, however, preclude sexual pleasure, or the use of ancient cosmetic texts as a kind

49 See Moerman 2003 and Geertz 1973.

50 Dickie 2001: 16-17. The word philtron and its calque in latin - amatorium may have roughly the same range of meanings although the terms are restricted to the procedures of erotic magic.

51 Tr. Preus 1988: 88.

52 Totelin (private communication). 
of pornography. Breath fresheners, face creams and remedies against freckles, dandruff, toothpaste, alopecia and spots, remedies to whiten scars, hair dyes, depilation creams all point to a lively market for beauty recipes, products and self-improvement in the pursuit of love, sex and marriage. These were Galen's 'vices of embellishment', the concern of all women but not the legitimate cosmetic work of medicine (Galen disingenuously includes his own versions to save women from danger). ${ }^{53}$

What of the remedies designed to enhance sexual performance? Totelin again: 'the Hippocratic compilers of recipes made use of a vast array of ingredients that were sexually connoted, but the gynaecological treatises do not explain efficacy beyond ascribing it to the treatment by opposites i.e. curing dry vagina with moist figs'. ${ }^{54}$ Speaking of the Scythians the Hippocratic treatises Airs, Waters Places states that 'people of such a constitution cannot be prolific. The men lack sexual desire because of the moistness of their constitution and the softness and coldness of their bellies, a condition which least inclines men to intercourse'. ${ }^{55}$ The remedies to charge up the Scythian constitution, it stands to reason, must be heating food and drugs.

Aphrodisiac efficacy was partly established through what has come to be known, since Paracelsus, as the 'doctrine of signatures', the similarity of plant morphology with parts of the body. Plant bulbs, especially the orchid, enhanced male sexual performance for their being reminiscent of testicles; other plants commonly cited are eruca sativa (rocket, arugula), arugula with honey and spices which might enhance an erection and when laced with saturia (aphrodisiac bulbs) would increase both size and pleasure. ${ }^{56}$ Theophrastus described a penis cream that could cause 'twelve erections in succession'. ${ }^{57}$

A combination of the exotic, the wild and the rare, with the power of the doctrine of signatures in an ingredient was apparently very exciting: Cyranides, writing on the wild pig (suagros) states that 'its testicles, dried and crushed as a drink, incite to the sexual act'. Eggs from the partridge 'incite to the sexual act'. ${ }^{58}$ Tail of the lizard or the deer, molar of the skink, brain of the crane, womb of the hare, the salpe fish, animals and birds like goats and sparrows noted for their sexual pro-

\footnotetext{
53 Totelin (forthcoming).

54 Totelin 2009: 207.

55 Tr. Chadwick and Mann 1978: 165.

${ }^{56}$ Faraone 1999: 10, n. 93, and 20 . The general meaning of saturia and the intriguing penis cream alert us to the problem of matching plant and mineral names to modern terminology. We have tackled this problem as best we can. General categories for species such as orchid, or the terms for common substances such as 'egg' are undoubtedly correct, but terms we translate as 'mallow' or 'realgar' can only be read with the usual caution. We follow traditional and dictionary conventions that are open to challenge on account of the variations of plant terminology from one place to another and the inevitable distortions of modern categories.

57 Theophrastus HP 9.18.9 (also cited by Pliny NH26.99)

58 Cyranides 2.35, 2.47, 3.38.
} 
clivity were all ascribed sexual potency. ${ }^{59}$ They could be consumed, worn as a bracelet, carried on the hand or rubbed on the body. ${ }^{60}$ Metrodora the author, some claim, of the oldest medical text written by a woman, writes:

Recipes that are pleasurable: take the womb of a hare fried in a bronze frying pan, add 3 litrai of rose oil, then mix with sweet perfume, fat (4 drachmai), excrement of crocodile ( $3 \mathrm{dr}$.), sap of the plant scorpion, blood-red sumach $\left(2 \mathrm{dr}\right.$.), honey ( $4 \mathrm{dr}$.). Some add also a little fat of sparrow. ${ }^{61}$

There is a small step from observing that two things that have the same physical structure are likely to exert a mutual influence to noticing that activities shared by humans and animals might both be enhanced by the same substance. There are many tales in the ancient world where the substances used to encourage stud animals to mate gain a reputation for stimulating human sexuality. Theophrastus comments 'in Achea, and especially around Kerynia there is a kind of vine whose wine makes pregnant women abort; if bitches eat the grapes they also abort' ${ }^{62}$ Pliny describes how wines laced with the elusive saturion and hippomanes were used to stimulate sexual desire in horses. ${ }^{63}$ Yinyang huo 淫羊蕉 (Horny Goat Weed; Epimedium) gets its Chinese name from a story about a Chinese goatherd who discovered its magic after repeatedly observing its effect on his flock. ${ }^{64}$ Epimedium contains icariin a muscle relaxant that exerts a mild biochemical action on the penis similar to Sildenafil, the active ingredient of Viagra.

For the most part the Greek aphrodisiac recipes were simples. Pliny offers many special plants that could increase a man's potency such as terebinth and donax. $\mathrm{He}$ also cautions the anti-aphrodisiac effects of herbs such as numphea which relaxed the phallus, or lettuce, agnus castus, rue, or condrille which limited desire in different ways ${ }^{65}$ Valuing the work of those with on-the-ground experience, Theophrastus claimed that his information came from the pharmakopolai and the root-cutters. Assertions like a drug 'from a man from India' could make a man have tireless sexual energy also suggest hearsay. Multi-substance remedies, as are found in the early Chinese recipe tradition, come sometime after with Nicander (fl. second century BCE), Dioscorides (fl. first century BCE), and Galen. Galen's Simple Remedies, for example, states that, 'concerning turnip gongulis, the seed of turnip leads to sexual desire'. ${ }^{66}$ But many of the simples were infused in wine which was the vehicle for their action -- a sure way to achieve part of the desired aphrodisiac effect.

59 Faraone 1999: 20, n. 90.

60 Faraone 1999: 19.

61 Metrodora 36 ed. Del Guerra 1994: 52-53 tr. courtesy of Laurence Totelin.

62 Theophrastus HP 9.18.3-11. tr. Preus 1988.

63 For saturion see 26.99; hippomanes see Pliny NH8.165, 26.181; Faraone 1999: 21.

64 From Mingyi bielu 名醫別錄 (Separate Records of Eminent Physicians) as cited in Bencao gangmu juan 12.

65 Faraone 1999: 19; Lloyd 1983; For terebinth see Pliny NH24.28; donax 24.87; numphea 25.75; lettuce 19.127; agnus castus 16.26, 110; rue 34.89; condrille 22.91 .

$66 \mathrm{~K} 11.861$. 
We can see many aphrodisiac substances in ancient China, and especially those that are sexually connoted like asparagus for the shape of its head and the way in which it grows so erect in the ground. They were clearly used for their erotic rather than reproductive value. This was also the domain of longevity practices where new medical ideas were forming. Here is Da Cheng's 大成 (Great Perfection) response to the Yellow Emperor on being asked how to refine ones' complexion and delay aging. Da Cheng was an established authority in esoteric teaching.

\begin{abstract}
When coitus with Yin is expected to be frequent, follow it with flying creatures. The spring dickey bird's round egg arouses that crowing cock. The crowing cock has an essence. If you are truly able to ingest this, the jade whip is reborn. Best is engaging the member. Block that jade hole. When brimming then have intercourse, and bid farewell with round eggs. If the member is not engaged conserve it with roasted-wheat meal. If truly able to ingest this, you can raise the dead. ${ }^{67}$
\end{abstract}

Here, in what is a set of questions exploring longevity and immortality and its association with sexual competence into old age, the language is replete with euphemisms for the penis (the crowing cock, Yin, jade whip, the member) and the vagina (jade hole). Potency and fertility are represented by the round egg and avian creatures, and simultaneously strengthened by eating eggs and sustained with roasted-wheat meal. When stripped of the literary allusions the methods seem quite ordinary. But here we also find new codes emerging that were ultimately to shape nutritional and medical theory.

The aphrodisiac recipes from the Mawangdui tomb contain all the methods associated with Aphrodite in the Greek tradition. There are recipes for sustained and larger erections, copious semen, and general strength of qi for virility, 'contraction' and 'increasing fineness' of the vagina, hair removal after childbirth and for curing genital swellings: asparagus with chicken breast and a whole black rooster to boil the offal of a young black dog, to be taken in the afternoon in whatever quantity required, beef, yam, cinnamon, wild ginger and wormwood combined with oyster and Qin Zanthoxylum (a variety of Sichuan pepper) increase strength. Snails charge up the 'horse' (penis). Pork fed on pine truffles stimulate the woman; cow horn, ginger and cinnamon soaked in vinegar and administered via a vaginal suppository increase her 'craving'. ${ }^{68}$

With food and sex the stuff of everyday life it is easy to imagine how basic empirical observations about the effects or substances on the body could first be noticed by the authors and compilers of those recipes, and second, feed in to scholarly reflections on the nature of the body and its physiology. Evidence of this process is easily discernible in the body of the aphrodisiac recipes and, in this

${ }^{67}$ MWD 4 (Shiwen) nos. 10-14. Harper 1998: 389.

68 Ibid. 
respect, contrasts with the style of those prescriptions excavated from the same tomb that are aimed at the treatment of other peoples' diseases. Where the recipes for stimulating one's own sexual appetite, pleasure, and strengthening and conditioning the genitals are replete with techniques to rid the body of foul qi, to fortify, renew and strengthen Yin and qi, the collections designed for treating illness [rather than increasing a sense of strength and well-being] have barely any recourse to these terms of the emerging science. Neither can they be read against an esoteric literature framed in its terms. It is therefore to those texts that are concerned with self-experimentation and cultivation that we must turn to trace the history of the interface between the remedies and techniques of the ancient world and the new world that we now associate with the authority of classical medicine.

Measuring and controlling the internal sensory environment of the body is particularly evident in those aphrodisiac recipes that aim to 'Cause Burning', 'Increase Craving' and 'Cultivate Strength'. The fruits of the pagoda tree make the body 'seem[s] to itch but does not itch', a vivid evocation of sexual ardour; various degrees of heat, from subtle to intense, are identified on different surfaces of the skin as the effect, for example, of inserting honey, ginger and cinnamon soaked suppositories and massaging with napkins; wild ginger, curled cinnamon, ginger and monkshood increase qi and make a person's face lustrous. Woven cloths soaked in red ants and blister beetles, a universally attested irritant used as an aphrodisiac and known to us as Spanish fly, rubbed on 'the jade whip' startle the horse into action. ${ }^{69}$ Dried horsemeat and monkshood soaked in alcohol make the 'six extremities strong and increase longevity' while other alcoholic preparations made from fermented millet and herbs 'when ingested for one hundred days, [it] make[s] the eyes bright and ears perceptive; the extremities all become strong...' Interspersed with the aphrodisiac recipes are more general categories which contain prescriptions for strengthening the body which align sexual prowess with an overall concern for potency and the general sense that this condition of well-being was consistent with a prospect of prolonging life. ${ }^{70}$

Spellbinding and recipe literature detailing ingredients and practical techniques for entrancing lovers and increasing their sexual desire and performance contrasted with the poetry of the more theoretical literature of the sexual arts with its appeal to new styles of understanding the human body in its relation to the natural, social and cosmological environment. Apart from the more frequent references to Yin, Yang and qi the aphrodisiac remedies are structured like the recipes for curing illness, with content lists and category markers, for easy access and retrieval. The aphrodisiac collection, however, ends with a 'discourse' that marks it clearly as a text that stands between the ancient worlds of empirical and ritual healing and the formation of classical medical and nutritional theory. In a brief concluding section that serves to contextualise the remedies the legendary $\mathrm{Yu}$ 禹 is in conversation with his consorts about the perils of excessive sex and

\footnotetext{
69 Harper 2005: 91-100.

${ }^{70}$ Lo, V (forthcoming, 2016-7).
} 
the subsequent loss of qi. His stated desire is to "bring together qi so that man and woman propagate'. 'Young Beauty' warns against violent engagement and suggests a broth of woolly grass and mugwort to restore him. Thus this endnote suggests that the aphrodisiac literature cannot be read in isolation from the more theoretical treatises on the nature and purpose of sexual union and the techniques themselves. This one reference to 'propagate' is the exception that produces the rule. There is no remedy in this collection that deals directly with reproduction, fertility, or virility in relation to producing children. Most directly address sexual competence, pleasure, generalised strength and long life. ${ }^{71}$

Does the aphrodisiac record of ancient China mark a transition between passive observation and deliberate research, where the latter involves an active desire to extend knowledge?[1] We have demonstrated a community of researchers engaged in the collection and organisation of data collected through a range of sensory experiences. In what is surely the earliest surviving map of the female genitals appended to one of the aphrodisiac collections we see observation of an idealised anatomy, a line drawing marking pubic hair, locating vaginal aromas choushu 臭鼠 (the smelly rat), and the chizhu 赤珠 (red pearl', a euphemism for the clitoris), designed like a control panel in the pursuit of knowledge and power. This is a remarkable diagram, demanding further analysis, but which for our purposes testifies to the range of senses through which information about sexual response was hypothesised and recorded in early China. ${ }^{72}$

While there is both intentionality and theory involved in the matching of animal to human contexts, and traditional knowledge always presupposes an on-going accumulative process of trial and error, in this combined recipe and theoretical literature, devoted to the sexual arts, we find a specialist literacy and images which demonstrate new and sustained styles of recording observations and sensory perceptions of the body - valuable records of the collective experimentation of a new group of learned self-experimenters. While we cannot locate this project in any particular institution, it is clear that it is part and parcel of a widespread medical culture that was operating through the new networks of knowledge that spanned the Yellow River plains and Yangzi valley in the early centuries of empire.

\section{CONCLUSION}

While disparaging the over-elaborated correlations of turn-of-the-millennium 'proto-science' as 'a low point in the debasement of Chinese thought', Angus Gra-

\footnotetext{
71 Regular comments that a recipe has been 'tested' or is 'excellent' suggest there was a hierarchy of good cures established by precedent. Where remedies rely on belief in the direct involvement of the spirit world, the anthropologist's distinction between 'efficacy' and 'felicity', or the 'meaning response' as identified by Moerman, help gauge the excellence of their contemporary appropriateness, but this hardly explains the full range of connotations. High praise may also simply be a marketing ploy.

72 Ma Jixing 1991: 748.
} 
ham made an important point. In China, correlative thinking, exemplified in YinYang and Five Agent cosmology, extended easily in to what, in other contexts, might be thought of as sympathetic magic or sumpatheia as often discussed by Greeks and Romans. ${ }^{73}$ Thus Yin-Yang divisions of the body, astronomy, astrology and the planetary gods and spirits existed on a continuum, and were embraced within the same natural order. ${ }^{74}$ The kind of observations about resonance and mutual influence between things of the same form and nature is as much at the core of ritual magic and binding spells as it is in translating animal behaviour to the human world. We have provided examples of these records for the ancient worlds of Greece and China.

Some of the recipes recorded are based on millennia of collective belief and empiricism, anonymous records of the accumulating experience of healers, farmers and root gatherers. Others are the result of a learned community of individuals who contributed their work, still anonymously, to a burgeoning body of technical literature. The Chinese aphrodisia, we have argued, stand at the threshold where what one might imagine as the simple empiricism of the former met the learned approaches with which scholars recorded their experience of the body and its care.

The language and structure of key aphrodisiac remedy collections have provided the clearest evidence of the empirical process merging with the new medical theories of Yin, Yang, Qi and Jing, for the reason that they reflect the experiences of the body in self-experimentation. This was an intimate process that involved a community of learned practitioners whose aesthetic engagement with their scientific objects (the self, and sexual partners) required comprehensive sensory perception and not just the singular and limiting observations of the eye. This process is not evident in the parallel Mawangdui medical recipe texts for treating patients, that is other people, with named illnesses, and therefore indicates that the sexual arts were a key context for medical innovation. To our knowledge, thus far, there is also no reason to believe that in the ancient Greek world aphrodisiacs and the sexual arts formed a special context for the development of medical theory. And this marks a major point of difference.

In this chapter we have surveyed a much-overlooked subject in the History of Medicine. We have done so comparatively demonstrating, categories, definitions, concepts and techniques of the sexual arts that were shared in the ancient worlds. Key differences we have discovered include the overarching reproductive aims of Greco-Roman aphrodisiac recipes, and the unique Chinese use of selfexperimentation in the sexual arts as a cornerstone of a new medicine. We hope that this small beginning will inspire others to consider serious study of aphrodisia as a contribution to the history of the 'scientific self'.

73 Graham 1989: 349-50.

74 Graham 1989: 382. 
HP Historia Plantarum

K Kühn

MWD Mawangdui

$\mathrm{NH} \quad$ Natural History

\section{ABBREVIATIONS}

\section{BIBLIOGRAPHY}

Allan, S. (1997) The Way of Water and Sprouts of Virtue. Albany, NY.

Alter, J. S. (2013), 'Sex, Askesis and the Athletic Perfection of the Soul', in Subtle Bodies eds. G. Samuels and J. Johnson (2013). London: 121-148.

Andreini, A. (2006), 'The Meaning of qing 情 in Texts from Guodian Tomb No. 1', in Love, Hatred, and Other Passions: Questions and Themes on Emotions in Chinese Civilization eds. P. Santangelo and D. Guida, Leiden: 149-65.

Bain, D. (1997), 'Salpe's Maíyvıa: Athenaeus 322A and Plin. H.N. 23.38,' Classical Quarterly, 48: 262-8.

Bjorck, G. \& Farrington, B. (1944) Apsyrtus, Julius Africanus et I'Hippiatrique grecque (Uppsala Universitets Arsskrift. 1944: 4). Journal of Hellenic Studies 64:121.

Bray, F., Dorofeeva-Lichtmann, V. and Metailié, G., (2007) Graphic and Text in the Production of Technical Knowledge in China: The Warp and the Weft, Leiden

Chadwick J. and W.N. Mann (1950), The Medical Works of Hippocrates, Oxford.

Calverley, C.S. (1869) Theocritus: translated into English verse. Cambridge.

Daston, L. and Gallison, P. (2010) Objectivity. New York.

Del Guerra, Giorgio (1994) Metrodora, Medicina e cosmesi ad uso delle donne : la antica sapienza femminile e la cura di sé. Milan

Dickie M. (2001), Magic and Magicians in the Graeco Roman World. Abingdon.

Erickson, S. N. (2010) 'Han Dynasty Tomb Structures and Contents', in China's Early Empires: A Reappraisal, eds. M. Loewe and M. Nylan, Cambridge: 13-82.

Faraone, C. A. (1996) 'Taking the "Nestor's Cup Inscription" seriously: erotic magic and conditional curses in The earliest inscribed hexameters' , Classical Antiquity, 15: 77-112.

(1999) Ancient Greek Love Magic. Massachusetts and London.

Faraone, C. A. and Obbink, D. (1991) Magika Hiera: Ancient Greek Magic and Religion. Oxford.

Fortenbaugh, W. and Sharples, R. W. (1988) Theophrastean Studies, On Natural Science, Physics and Metaphysics, Ethics, Religion and Rhetoric (RUSCH III). New Brunswick.

Geertz, Clifford (1973) The Interpretation of Cultures: Selected Essays. New York

Gemmill, C. L. (1973) 'The missing passage in Hort's translation of Theophrastus', Bulletin of the New York Academy of Medicine, 49.2: 127-9.

Geurts, K. L. (2005) 'Consciousness as "Feeling in the Body": A West African Theory of Embodiment, Emotion and the Making of Mind', in Empire of the Senses: The Sensual Culture Reader, eds. D. Howes. Oxford: 164-78.

Goldhill, S. (2004) Love, Sex and Tragedy: how the ancient world shapes our lives. Chicago. 
Graham, A. (1989) Disputers of the Dao: Philosophical Argument in Ancient China. La Salle, IL.

Griffith, F. L. and Thompson, H. (1921) Demotic Magical Papyrus of London and Leiden. Oxford.

Harper, D. (1998) Early Chinese Medical Literature: The Mawangdui Medical Manuscripts. London. (2005), 'Ancient and Medieval Chinese Recipes for Aphrodisiacs and Philters', Asian Medicine, 1. 1, 91-100.

Hort, A. (1980) Theophrastus, Enquiry into plants: and minor works on odours and weather Signs,. Cambridge, MA.

Howes, D. (2005) Empire of the Senses: The Sensual Culture Reader. Oxford: 164-78.

Hsu, E. (2001) Innovation in Chinese Medicine. Cambridge.

(2010) Pulse Diagnosis in Early Chinese Medicine: The Telling Touch. Cambridge.

Humphreys, S. (1993) The Family, Women and Death. Michigan.

Hunan sheng bowuguan 湖南省博物馆 and Zhongguo kexueyuan kaogu yanjiusuo 中国科学院考古研究所 (eds) (1973), Changsha Mawangdui yihao Hanmu 长沙马王堆一号 汉墓. Beijing.

James S. L. and Dillon, S. (2012) Blackwell Companion to Women in the Ancient World. Malden, MA.

Jordan, D. (1985) "A survey of Greek Defixiones not Included in the Special Corpora," in Greek, Roman and Byzantine Studies 26: 151-197.

Jütte, R. (2005) A History of the Senses: From Antiquity to Cyberspace, tr. J. Lynn. Oxford.

Keuls, E. C. (1993) The Reign of the Phallus. Berkeley.

Kühn, C. G. (1964) Claudii Galeni opera omni. Hildesheim.

Kuriyama, S. (2002) The expressiveness of the Body and the Divergence of Greek and Chinese Medicine. Cambridge, MA.

Lau D. C. (1970), Mencius, London: Penguin Books.

Lanselle, R. (2003) Du Pouvoir. Paris.

Li Jianmin 李建民 (1996), 'Furen meidao kao: chuantong jiating de chongtu yu huajie fangshu'婦人媚道考：傳統家庭的衝突與化解方術, Xin shixue, 7.4 (1996), 1-32.

Li Ling 李零 (2001), Zhongguo fangshu kao 中國方術考 (Studies of Chinese divinatory and medical arts), Beijing: Dongfang chubanshe.

(2006), Zhongguo fangshu zhengkao 中國方術正考 (Revised studies of Chinese divinatory and medical arts), Beijing.

Li Shizhen (Ming) (2002) Bencao gangmu 本草纲目, Xin jiaozhu ben, ed. Liu Hengru et al., 2 vols, Beijing.

Liu Lexian 刘乐贤 (2005) 'Love charms among the Dunhuang manuscripts', in eds. V. Lo 
and C. Cullen: 165--175.

Lloyd, G. E.R. (1979) Magic, Reason and Experience. Cambridge.

(1983) 'Theophrastus, the Hippocratics and the Root Cutters: Science and the folklore of plants and their use', in Science Folklore and Ideology: Studies in the Life Sciences in Ancient Greece. Cambridge: 119-135.

(1987) The Revolutions of Wisdom, Berkeley, Los Angeles, London.

(1996) Adversaries and Authorities: Investigations into ancient Greek and Chinese Science. Cambridge.

Lo, V. (2000) 'Crossing the "Inner Pass": An"Inner/Outer" Distinction in Early Chinese Medicine?', East Asian Science,Technology and Medicine, 17,, 15-65.

(2001) 'The Influence of Western Han Nurturing Life Literature on the Development of Acumoxa Therapy', in Innovation in Chinese Medicine, eds. E. Hsu. Cambridge: 1951.

(forthcoming 2015-16), Potent Substances: on the boundaries between food and medicine, London.

Lo, V. and Cullen, C. (2005) Medieval Chinese Medicine, London.

Lo, V. and Barrett, P. (2012) 'Other Pleasures?' in Sex in Asia, 400-1900, eds. R. Reyes. London: 25-46.

Loewe, M. (1974) Crisis and Conflict in Han China, London.

Loewe, M. and Nylan, M. (2010) China's Early Empires: A Re-appraisal. Cambridge.

Lonie, I. (1981) The Hippocratic Treatise, 'On Generation', 'On the Nature of the Child', 'Diseases IV. Berlin.

Ma Jixing 馬繼興 (1992) Mawangdui guyishu kaoshi 馬王堆古醫書考釋, Hunan.

Mawangdui Hanmu boshu zhengli xiaozu 马王堆汉墓帛书整理小组 (eds.) (1985), Mawangdui Hanmu boshu 馬王堆漢墓帛書 vol. 4, (MWD 4) Beijing.

McClure, L. K. (2002) Sexuality and Gender in the Classical World: Readings and Sources. Oxford.

Moerman, D. (2002) Meaning, Medicine and the 'Placebo Effect', Cambridge.

Nutton, V. (2004) Ancient Medicine, London.

Nylan, M. (2003) 'On the Politics of Pleasure', Asia Major, 3rd series, 14.1: 73-124.

Ovid (1929) Art of Love. Cosmetics. Remedies for Love. Ibis. Walnut-tree. Sea Fishing. Consolation, tr. J. H. Mozley. Cambridge, MA.

Parker, H. N. (1992) 'Love's body anatomized; the ancient erotic handbooks and the rhetoric of sexuality', in eds. A. Richlin. Pornography and Representation in Greece and Rome, Oxford: $90-111$.

(2012) "Women and Medicine," in Blackwell Companion to Women in the Ancient World, eds. S. L. James, S. Dillon. Malden, MA: 107-24.

Pfister, R (2012) 'Gendering Sexual Pleasures in Early and Medieval China', Asian Medicine 7.1: 34-64.

Pliny (1940) Natural History, Volume III: Books 8-11, tr. H. Rackham. Loeb Classical Library. (1950) Natural History, Volume V: Books 17-19, tr. H. Rackham. Loeb Classical Library. 
(1951) Natural History, Volume VI: Books 20-23, tr. W. H. S. Jones. Loeb Classical Library.

(1956) Natural History, Volume VII: Books 24-27. tr. W. H. S. Jones, A. C. Andrews. Loeb Classical Library.

Potter, P (2012) Hippocrates, Volume X. Generation. Nature of the Child. Diseases 4. Nature of Women and Barrenness. Cambridge, MA.

Preisendanz, K. and Henrichs, A. (1973-4) Papyri Graecae Magicae: Die griechischen Zauberpapyri. Stuttgart.

Preus, A. (1988) 'Theophrastus' Phychopharmacology (HISTORIA PLANTARUM IX)', in Fortenbaugh and Sharples: 76-99.

Samuel, G. B. and Johnston, J. (2013) Religion and the subtle body in Asia and the West: between mind and body. Routledge Studies in Asian Religion and Philosophy, Vol. 8. London.

Qiu Xigui 雸錫圭 (1992), 'Mawangdui yishu shidu suoyi’ 馬王堆醫書釋讀瑣議, in Guwenzi lunji 古文字論集 (A Collection of Essays on Ancient Texts), Beijing: 528-9.

Richlin, A. (1992) Pornography and Representation in Greece and Rome. Oxford.

Sakade Y. 坂出祥伸 and Umekawa S. 梅川純代 (2003),

「気」の思想から見る道教の房中術：いまに生きる古代中国の性愛長寿法 ‘Ki' no shisō kara miru dōkyō no bōchūjutsu : ima ni ikiru kodai Chūgoku no seiai chōjuhō. Tōkyō.

Santangelo, P. and Guida, D. (2006) Love, Hatred, and Other Passions: Questions and Themes on Emotions in Chinese Civilization. Leiden.

Sarton, G. (1959) A History of Science. Cambridge, MA.

Scarborough, J. (1978) 'Theophrastus on herbals and herbal remedies', Journal of the History of Biology, 11: 353-85.

(2010) Pharmacy and Drug Lore in Antiquity: Greece, Rome, Byzantium. London.

Stanton, D. C. (1992) Discourses of Sexuality: from Aristotle to Aids. Ann Arbor, MI: 48-77.

Sterckx, R. (2003) 'Le Pouvoir des Sens: Sagesse et Perception Sensorielle en Chine Ancienne', in eds. R. Lanselle Du Pouvoir. Paris : 71-92.

Suzuki, A. and Hisaro, I. (2005) 食䬲の技法一身体医文化論 4 (Art of Eating Medical Culture of the Body, 4), Tokyo.

Totelin, L. M. V. (2009), Hippocratic Recipes: Oral and Written Transmission of Pharmacological Knowledge in Fifth- and Fourth-Century Greece. Leiden. (forthcoming), 'From techê to kakotechnia: use and abuse of ancient cosmetic texts'

Umekawa, Sumiyo 梅川純代 (2005), “媚薬一中国性技法における食 (The Aphrodisiacs - Diet in Chinese Sexual Art)', in eds. S. Akihito and I. Hisaro 食䬲の技法一身体医文論 4 (Art of Eating - Medical Culture of the Body, 4),Tokyo: 93-216.

Vieillefond, J. (1970) Les 'Cestes' de Julius Africanus: Etude sur l'ensemble des fragments avec édition, traduction et commentaires, Florence: Institut Français, 1970.

Wear, A. (2013) 'Popular medicine and the new science in England: cross roads or merging lanes?' in eds. K. von Greyerz, S. Flubacher, P. Senn. Wissenschaftsgeschichte und Geschichte des Wissens im Dialog. Schauplaetze der Forschung: 61-84. 
Winkler, J. (1992) The Constraints of Desire, the Anthropology of Sex and Gender in Ancient Greece. New York. 